\title{
CHARACTERISTICS OF RAINFALL AND PRECIPITABLE WATER IN THE ANNUAL AND SEMIANNUAL RAINFALL IN THE AREA WITH VARIOUS INTENSITY OF EL NINO (SUMATERA CASE STUDY)
}

\author{
Agus Safril* \\ Sekolah Tinggi Meteorologi, Klimatologi, dan Geofisika, Indonesia \\ *Corresponding Author Email: agus.safril@ stmkg.ac.id
}

Received: 28 March 2020

Revised: 1 April 2020

Accepted: 4 April 2020

Online: 26 April 2020

Published: 30 April 2020

SPEKTRA: Jurnal Fisika dan Aplikasinya p-ISSN: 2541-3384 e-ISSN: 2541-3392

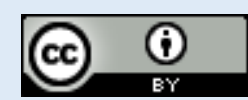

\begin{abstract}
Indonesia has various islands lying in the maritime continent surrounded by oceans with strong cloud convection. El Nino events, whether at weak, medium or, strong intensity, have the potential to cause different convection effects. Based on these conditions, it is necessary to analyze the characteristics of rainfall when El Nino occurred in Sumatra. The analysis was carried out by looking at the percentage of dominant frequency events of Below Normal (BN), Normal (N), and Above Normal (AN) rainfall in El Nino years. The analysis was also carried for the relationship between the content of precipitable water and sea surface temperatures in the Central Pacific (Nino of 3.4 indexes). The analysis results show that the effect of El Nino (in the annual rain cycle) is stronger than the region with the semi-annual rain cycle. The annual rain cycle area in the El Nino intensity category is weak, medium, strong (predominantly BN-N rain characteristics). In the semi-annual rainfall cycle (rainfall between $\mathrm{N}-\mathrm{AN}$ ) it is medium (BN-AN), and strong (N-BN). The average composite percentage in the years of El Nino shows a weak intensity with the average of rain BN between 37-50\%, medium (42-53), and strong (42-48\%). Whereas in the annual cycle region, the average rainfall characteristics of the BN category are weak (50-58\%), moderate (36-56\%), and strong (32$60 \%$ ). Characteristics of different rain characteristics are due to differences in the atmospheric ability to capture moisture. Correlation in the region with the annual rain cycle (June-July-August) between the Nino 3.4 Index and the precipitable water content shows a strong (r) correlation ( -0.4 to $0.6)$. This is in contrast with the region semi-annual rain cycle, which shows a weaker correlation $(0.2$ to 0.3$)$.
\end{abstract}

Keywords: El Nino intensity, rainfall cycle, 3.4 Nino Index, precipitable water 


\section{INTRODUCTION}

Sumatra region is vulnerable to forest and land fires. Knowledge of El Nino Southern Oscillation (ENSO) that causes rainfall anomalies is needed by local governments and other stakeholders to mitigate natural disasters. El Nino is a climate anomaly event that causes the characteristics of rainfall in Indonesia decreased [1]. Actions are needed when El Nino intensity is different; therefore, the right mitigation in a region can be undertaken. The results of previous studies indicate that there is a difference in rainfall cycles between the two regions of northern Sumatra (the annual rain cycle) and the southern (the annual rain cycle) $[2,3]$. El Nino pattern has a stronger intensity in the dry season compared to the rainy season [4]. Based on these conditions, a study of the impact of El Nino is needed in both regions El Nino with strong intensity influences the lead and lag of the dry season period in Sumatra. Dry season shifts generally lead two to three decades of the El Nino Strong period [5]. Rainfall also affects the northern Sumatra region due to El Nino [6]. The influence of ENSO shows that sea surface temperature affects rainfall anomalies in Indonesia [7]. Under these conditions, it is also necessary to study the variability of rainfall when El Nino occurs under strong, moderate, and weak intensity.

To illustrate the monsoon pattern, several parameters can be used, including zonal wind and Precipitable Water. Zonal winds at an altitude of 850 millibars are also a parameter of the onset of the South China Sea monsoon system [8]. The zonal wind is also to identify anomalous rainfall due to ENSO [9]. Precipitable water (the potential for bulk water) further illustrates the physical characteristics of rainfall that is influenced by the potential for rainfall in the predicted region (maritime continent). The potential of this water vapor becomes a study to find out the characteristics in the annual and annual rain areas. Some PW characteristics to explore atmospheric physical conditions in Sumatra include the PW parameter that can capture the monsoon rainfall system [10] and has a strong relationship with the intensity of the monsoon [11], the monsoon variability that can be explained by the variation of precipitable water (PW) [12] and temporary increase in PW is indicated by the arrival of the monsoon [13]. Besides, PW is also spatially able to explain monsoon variability in spatial distribution as an effect of broad-scale atmospheric circulation [14]. PW analysis can use with reanalysis data (integration of model data and observation) to find out the beginning and variability of the monsoon [15]. The evolution of air humidity in the monsoon system can also be explained by PW [16], and PW can also explain synoptic-scale disturbance in the monsoon system [17]. Precipitable water can also describe climate change [18]. Based on this reason, it is necessary to study the characteristics of water vapor in the Sumatera monsoon system (semi-annual and annual rainfall) when a climate anomaly occurs.

\section{METHOD}

The data used for research are observation data and reanalysis. Rainfall data consists of 9 stations, consisting of Sabang, Banda Aceh, Lhokseumawe, Medan, and Pekanbaru which represent semiannual rainfall patterns. Stations representing the annual rainfall cycle consist 
of Jambi, Taman Bogo, Pangkal Pinang and Palembang. Rain data were obtained from the Meteorology, Climatology, and Geophysics Agency. The data year period is between 20 years from 1986-2015. Rain data observation station location as in FIGURE 1 below. El Nino index data and PW reanalysis data from the National Centers for Environmental Prediction (NCEP).

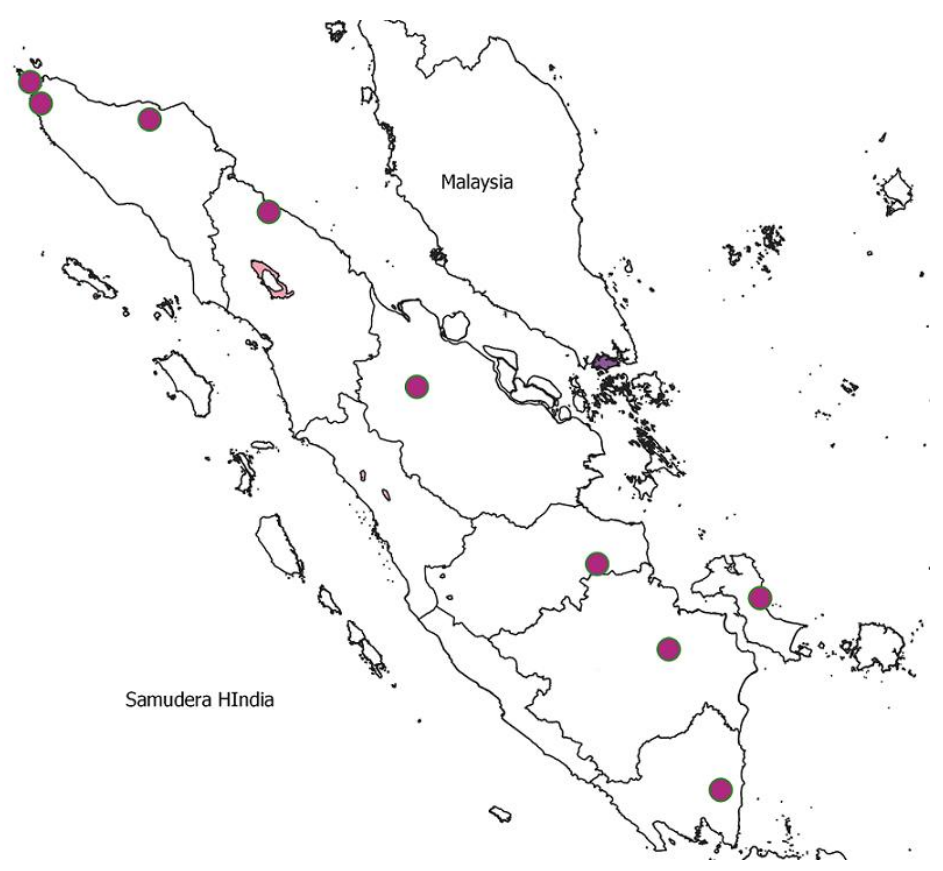

FIGURE 1. The research location consists of 9 Rainfall observer stations on the island of Sumatra

Preliminary analysis to determine the characteristics of rainfall by sampling a number of rainfall station points that represent semi-annual and annual rainfall patterns. Rainfall analysis was carried out in the El Nino years of strong, moderate, and weak intensity. The characteristic of rainfall is obtained from calculating the average in 1986-2015 (20 years) and then calculating the standard deviation (SD) every month. The Below Normal $(\mathrm{BN})$ is defined if monthly rainfall < monthly average - $0.5 \mathrm{SD}$, meanwhile Normal is defined if monthly rainfall average $-0.5 \mathrm{SD} \leq$ Normal Rainfall $\leq$ monthly rainfall average $+0.5 \mathrm{SD}$, and Above Normal $(\mathrm{AN})>$ monthly average $+0.5 \mathrm{SD}$. Furthermore, at each rain observation station, the frequency of rainfall below the BN, N and AN frequency was calculated. From these results obtained the dominant frequency (in the form of a percent) of the nature of rain.

In order to obtain information on the global influence on the nature of rainfall, an average (composite) percentage of rainfall in the years of El Nino occurred in various categories (strong, medium, and weak) was done at each of the rain observation station (TABLE 1). The results obtained are composite monthly averages from January to December. The rest are grouped into two annual and annual groups. 
TABLE 1. The intensity of the El Nino event years.

\begin{tabular}{lll}
\hline & El Nino Year Intensity & \\
\hline Weak & Moderate & Strong \\
$2004-2005$ & $1986-1987$ & $1987-1988$ \\
$2006-2007$ & $1994-1995$ & $1991-1992$ \\
$2014-2015$ & $2002-2003$ & $1997-1998$ \\
& $2009-2010$ & \\
\hline
\end{tabular}

Source: National Centers for Environmental Prediction (NCEP)

PW is a water vapor content that has the potential to become rain and is expressed in $\mathrm{kg} / \mathrm{m}^{2}$. Precipitable water is obtained by integrating specific humidity at each pressure level in oneatmosphere column, according to EQUATION 1, with $g$ is the acceleration due to gravity $\left(\mathrm{m} / \mathrm{s}^{2}\right), \mathrm{q}$ is the specific humidity $(\mathrm{g} / \mathrm{kg})$, and $\mathrm{p}$ is the atmospheric pressure (millibar) [19].

$$
P W V=\frac{1}{g} \int_{p 1}^{p 2} q d p
$$

Furthermore, from the dominant pattern of rainfall, an analysis of PW is carried out in various months from January to December, which forms the basis for the rainfall characteristics formation. The flow of research methods described in FIGURE 2. The final analysis concludes the relationship between rainfall and PW patterns with the El Nino index so that the characters are distinguished between the two regions.

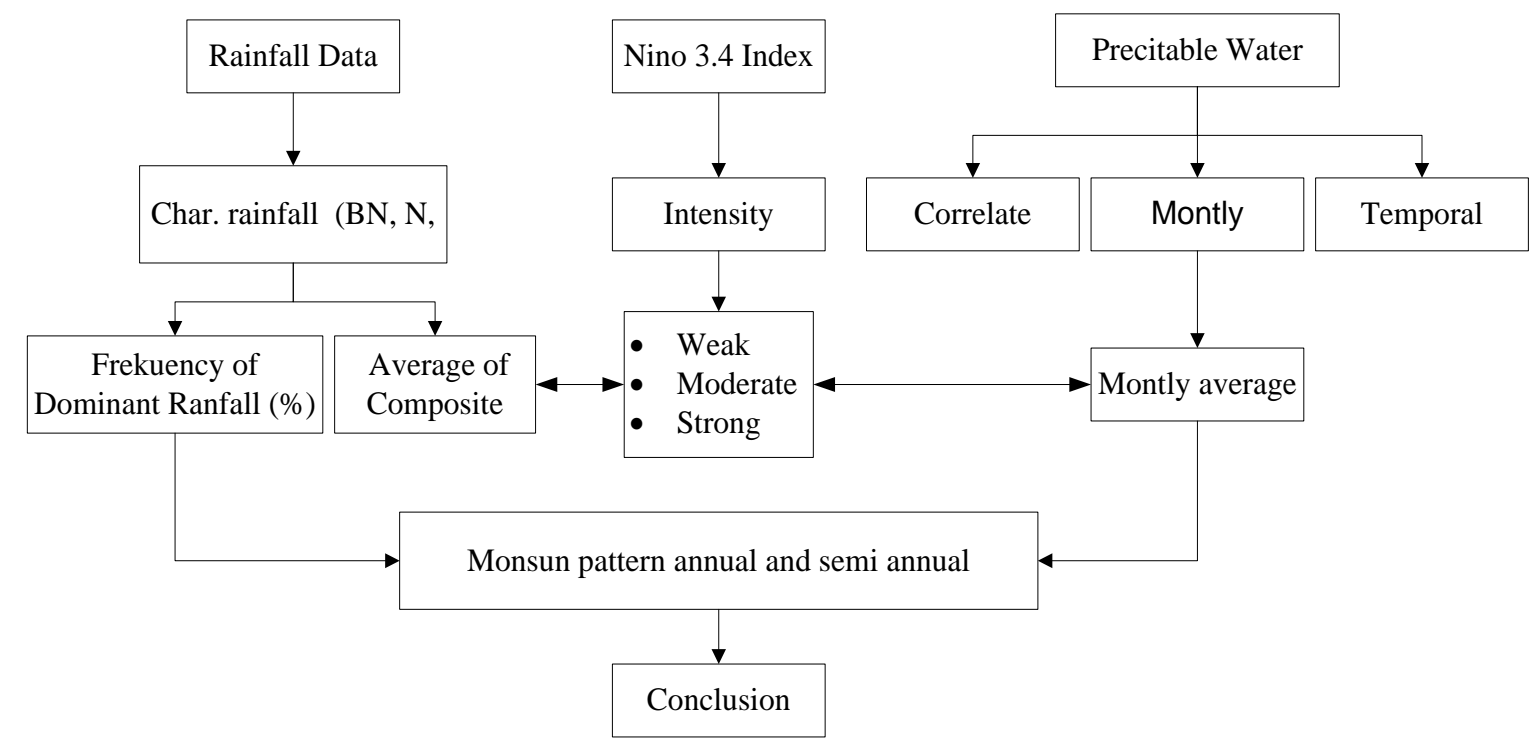

FIGURE 2. Research metodologi in Sumatera Area

\section{RESULT AND DISCUSSION}

\section{Dry season patterns in the Sumatra region}

The dry season pattern in the northern region is marked by calculating the average amount of monthly rainfall. When monthly rainfall reaches 150 millimeters of rain [18] is called the rainy season. Dry season criteria occur if rainfall is less than 150 millimeters as shown in FIGURE 3. It shows an example of the start of the season at a dry station that starts in February and 
ends in July at Sabang station (left), while June to October at Taman Bogo Station Lampung (right).
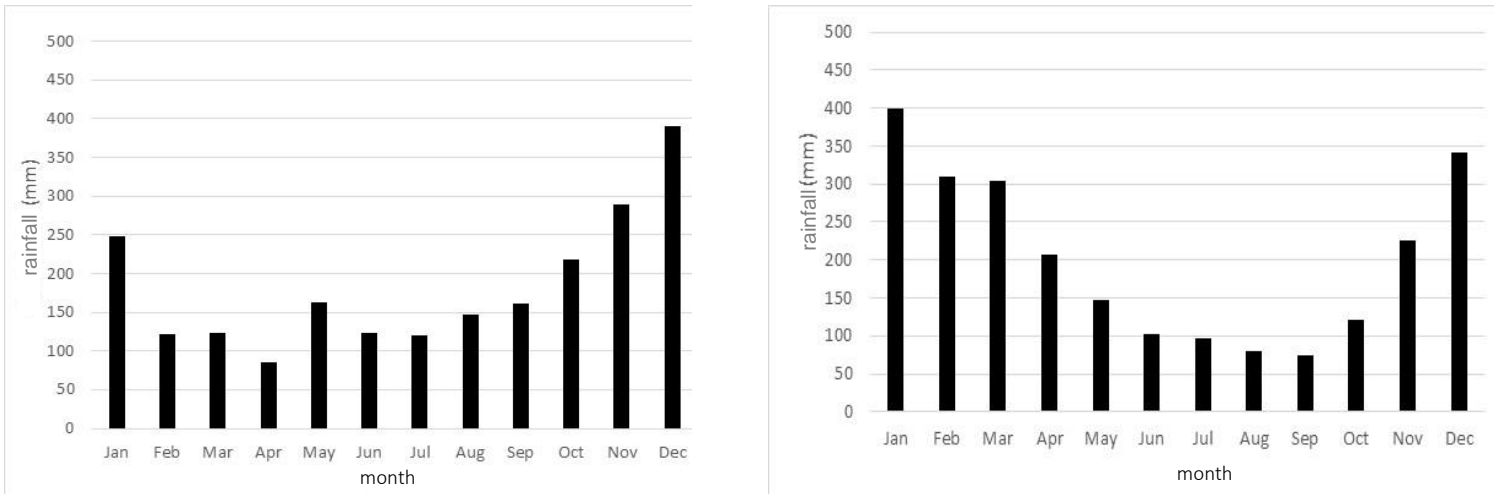

FIGURE 3. Sabang Station Average Rainfall (semi-annual) and Annual (Taman Bogo Lampung) in 1986-2015

\section{Patterns of northern Sumatra rain patterns in the El Nino period}

Results of the rain nature analysis from various El Nino conditions were carried out for the northern Sumatra region, for example, Sabang Station. The results of the dominant rain traits percentage in this region show that: the frequency of dominant rainfall traits BN to Normal with details of BN-N (38-63\%) in the category of weak El Nino intensity, BN-AN (moderate) is ranging from $29-50 \%$ and $\mathrm{BN}-\mathrm{N}$ is a range of $33-67 \%$ (strong) as shown in TABLE 1 . The percentage of the strongest BN events occurred in El Nino 1997-1998 (67\%).

TABLE 1. The characteristics of rain properties on El Nino intensity are weak, moderate and strong in the Sabang region.

\begin{tabular}{|c|c|c|c|c|c|c|c|c|}
\hline \multirow[b]{2}{*}{ Year } & \multicolumn{3}{|l|}{ Weak } & \multicolumn{2}{|c|}{ Moderate } & \multicolumn{3}{|c|}{ Strong } \\
\hline & $\begin{array}{l}\text { Charac- } \\
\text { teristic }\end{array}$ & $\begin{array}{l}\text { Persen- } \\
\text { tation }\end{array}$ & Year & $\begin{array}{l}\text { Charac- } \\
\text { teristic }\end{array}$ & $\begin{array}{l}\text { Persen- } \\
\text { tation }\end{array}$ & Year & $\begin{array}{l}\text { Charact- } \\
\text { eristic }\end{array}$ & $\begin{array}{l}\text { Persen- } \\
\text { tation }\end{array}$ \\
\hline \multirow[t]{3}{*}{$2004-2005$} & $\mathrm{AN}$ & $0 \%$ & 1986-1987 & AN & $20 \%$ & $1987-1888$ & $\mathrm{AN}$ & $0 \%$ \\
\hline & $\mathrm{N}$ & $63 \%$ & & $\mathrm{~N}$ & $33 \%$ & & $\mathrm{~N}$ & $67 \%$ \\
\hline & $\mathrm{BN}$ & $38 \%$ & & $\mathrm{BN}$ & $47 \%$ & & $\mathrm{BN}$ & $33 \%$ \\
\hline \multirow[t]{3}{*}{ 2006-2007 } & $\mathrm{AN}$ & $0 \%$ & 1994-1995 & $\mathrm{AN}$ & $57 \%$ & 1991-1992 & AN & $21 \%$ \\
\hline & $\mathrm{N}$ & $40 \%$ & & $\mathrm{~N}$ & $29 \%$ & & $\mathrm{~N}$ & $36 \%$ \\
\hline & $\mathrm{BN}$ & $60 \%$ & & $\mathrm{BN}$ & $14 \%$ & & $\mathrm{BN}$ & $43 \%$ \\
\hline \multirow[t]{6}{*}{ 2014-2015 } & $\mathrm{AN}$ & $23 \%$ & $2002-2003$ & $\mathrm{AN}$ & $13 \%$ & 1997-1998 & $\mathrm{AN}$ & $0 \%$ \\
\hline & $\mathrm{N}$ & $31 \%$ & & $\mathrm{~N}$ & $50 \%$ & & $\mathrm{~N}$ & $33 \%$ \\
\hline & $\mathrm{BN}$ & $46 \%$ & & $\mathrm{BN}$ & $38 \%$ & & $\mathrm{BN}$ & $67 \%$ \\
\hline & & & $2009-2010$ & $\mathrm{AN}$ & $25 \%$ & & & \\
\hline & & & & $\mathrm{N}$ & $50 \%$ & & & \\
\hline & & & & $\mathrm{BN}$ & $25 \%$ & & & \\
\hline
\end{tabular}

TABLE 1 shows that there is still one regional point, for the whole region in Sumatra, the spatial variation in rainfall characteristics is discussed. From TABLE 2 in general, the northern Sumatra region generally varies the dominant percentage of rainfall between BN-N (Sabang and Lhokseumawe) and several regions varying between BN-AN (Banda Aceh, Deli Serdang, 
and Pekanbaru) in all categories of El Nino intensity. The characteristics of the $\mathrm{N}$ to $\mathrm{BN}$ rain occur only in El Nino Strong. This pattern shows that the influence of El Nino for the northern Sumatra region is different for each region. Geographically, Sabang is a small island at the northern of Sumatra surrounded by the ocean of the northern Indian Ocean, Banda Aceh is in the lowlands, Lhokseumawe is surrounded by hills while Deli Serdang and Pekanbaru are lowlands. Different geographical characters cause different atmospheric convection processes from one region to another. Under these conditions, the global influence due to El Nino diminished when El Nino appeared in this region.

TABLE 2. The characteristic of rainfall in Northern Sumatra during the El Nino Period with weak, moderate, and strong strength.

\begin{tabular}{llllll}
\hline \multirow{2}{*}{ Category } & \multicolumn{5}{c}{ Region } \\
\cline { 2 - 6 } & Sabang & Banda Aceh & Lhokseumawe & Deli Serdang & Pekanbaru \\
\hline Weak & BN-N & N-AN & BN-N & N-BN & BN-N \\
Moderate & BN-AN & BN-AN & BN-N & N-BN & N-AN \\
Strong & BN-N & N-BN & BN-AN & N-BN & N-BN \\
\hline
\end{tabular}

To get information on the intensity of global climate anomalies (El Nino) in influencing the northern Sumatra region, the composite average was analyzed in the El Nino years. The average composite percentage of El Nino events in various categories shows a percentage below 50 percent in the BN category at all stations. This shows that the effect of El Nino which is not too strong in the northern Sumatra region. The effect of El Nino which is quite consistent with the region above $40 \%$ is only when the El Nino is in a strong category as describes in TABLE 3. This character shows there is a global influence for the northern Sumatra region of the $\mathrm{BN}$ rain nature with a weak intensity between $37-50 \%$, moderate (42-53\%) and strong (42$48) \%$.

TABLE 3. Average Composite rain properties in El Nino with Weak, Medium and Strong Categories

\begin{tabular}{|c|c|c|c|c|c|}
\hline \multirow{2}{*}{ No } & \multirow{2}{*}{ Station } & \multirow{2}{*}{$\begin{array}{l}\text { Characteristic of } \\
\text { Rainfall }\end{array}$} & \multicolumn{3}{|c|}{ El Nino } \\
\hline & & & Weak & Moderate & Strong \\
\hline \multirow{3}{*}{1} & \multirow{3}{*}{ Sabang } & $\mathrm{BN}$ & $48 \%$ & $40 \%$ & $48 \%$ \\
\hline & & $\mathrm{N}$ & $44 \%$ & $34 \%$ & $45 \%$ \\
\hline & & AN & $8 \%$ & $26 \%$ & $7 \%$ \\
\hline \multirow{3}{*}{2} & \multirow{3}{*}{ Banda Aceh } & $\mathrm{BN}$ & $29 \%$ & $42 \%$ & $41 \%$ \\
\hline & & $\mathrm{N}$ & $42 \%$ & $27 \%$ & $43 \%$ \\
\hline & & (AN & $29 \%$ & $31 \%$ & $16 \%$ \\
\hline \multirow{3}{*}{3} & \multirow{3}{*}{ Lhokseumawe } & $\mathrm{BN}$ & $50 \%$ & $48 \%$ & $42 \%$ \\
\hline & & $\mathrm{N}$ & $34 \%$ & $35 \%$ & $35 \%$ \\
\hline & & $\mathrm{AN}$ & $16 \%$ & $17 \%$ & $23 \%$ \\
\hline \multirow{3}{*}{4} & \multirow{3}{*}{ Deli Serdang } & $\mathrm{BN}$ & $37 \%$ & $38 \%$ & $44 \%$ \\
\hline & & $\mathrm{N}$ & $34 \%$ & $53 \%$ & $44 \%$ \\
\hline & & AN & $29 \%$ & $9 \%$ & $12 \%$ \\
\hline \multirow{3}{*}{5} & \multirow{3}{*}{ Pekanbaru } & $\mathrm{BN}$ & $38 \%$ & $15 \%$ & $48 \%$ \\
\hline & & $\mathrm{N}$ & $51 \%$ & $38 \%$ & $39 \%$ \\
\hline & & $\mathrm{AN}$ & $11 \%$ & $47 \%$ & $13 \%$ \\
\hline
\end{tabular}


An example of a point scale annual pattern in the annual rain cycle area is using the Kenten Station in Palembang (southern Sumatra). The results of the percentage of dominant rainfall characteristics in this region show a dominant pattern of BN-N (38-63\%) in the category of El Nino Weak intensity, BN-AN (moderate) is ranging from $29-50 \%$ and $\mathrm{BN}-\mathrm{N}$ (strong) as described in TABLE 4.

TABLE 4. The characteristics of rain properties on El Nino intensity is weak, moderate, and strong in the Kenten area of Palembang (Source: Data processing).

\begin{tabular}{|c|c|c|c|c|c|c|c|c|}
\hline & Weak & & & Moderat & & & Strong & \\
\hline Year & $\begin{array}{l}\text { Charac- } \\
\text { teristic }\end{array}$ & $\begin{array}{l}\text { Persen- } \\
\text { tation }\end{array}$ & Year & $\begin{array}{l}\text { Charac- } \\
\text { teristic }\end{array}$ & $\begin{array}{l}\begin{array}{l}\text { Persen- } \\
\text { tation }\end{array} \\
\end{array}$ & Year & $\begin{array}{l}\text { Charac- } \\
\text { teristic }\end{array}$ & $\begin{array}{l}\begin{array}{l}\text { Persen- } \\
\text { tation }\end{array} \\
\end{array}$ \\
\hline \multirow{3}{*}{$\begin{array}{l}2004- \\
2005\end{array}$} & AN & $50 \%$ & \multirow{3}{*}{ 1986-1987 } & AN & $67 \%$ & \multirow{3}{*}{$1987-1988$} & AN & $64 \%$ \\
\hline & $\mathrm{N}$ & $38 \%$ & & $\mathrm{~N}$ & $27 \%$ & & $\mathrm{~N}$ & $29 \%$ \\
\hline & $\mathrm{BN}$ & $13 \%$ & & $\mathrm{BN}$ & $7 \%$ & & $\mathrm{BN}$ & $7 \%$ \\
\hline \multirow{3}{*}{$\begin{array}{l}2006- \\
2007\end{array}$} & AN & $80 \%$ & \multirow{3}{*}{ 1994-1995 } & AN & $57 \%$ & \multirow{3}{*}{ 1991-1992 } & AN & $50 \%$ \\
\hline & $\mathrm{N}$ & $0 \%$ & & $\mathrm{~N}$ & $14 \%$ & & $\mathrm{~N}$ & $29 \%$ \\
\hline & $\mathrm{BN}$ & $20 \%$ & & $\mathrm{BN}$ & $29 \%$ & & $\mathrm{BN}$ & $21 \%$ \\
\hline \multirow{6}{*}{$\begin{array}{l}2014- \\
2015\end{array}$} & AN & $43 \%$ & \multirow{3}{*}{$2002-2003$} & AN & $38 \%$ & \multirow{3}{*}{ 1997- 1998} & $\mathrm{AN}$ & $67 \%$ \\
\hline & $\mathrm{N}$ & $50 \%$ & & $\mathrm{~N}$ & $38 \%$ & & $\mathrm{~N}$ & $25 \%$ \\
\hline & $\mathrm{BN}$ & $7 \%$ & & $\mathrm{BN}$ & $25 \%$ & & $\mathrm{BN}$ & $8 \%$ \\
\hline & & & \multirow{3}{*}{$2009-2010$} & AN & $63 \%$ & & & \\
\hline & & & & $\mathrm{N}$ & $25 \%$ & & & \\
\hline & & & & BN & $13 \%$ & & & \\
\hline
\end{tabular}

In the spatial analysis, the results of all stations for the southern Sumatra region in all El Nino categories (weak, medium, and strong) and stations (Kenten, Jambi, Lampung, and Tanjung Pinang) show the nature of rain between BN-N, as shown in TABLE 5. The dominance pattern of the BN-N in southern Sumatra shows the dominant influence intensity of El Nino global anomalies in this region.

TABLE 5. The nature of rain in Southern Sumatra during the El Nino Period with weak, moderate, and strong intensity.

\begin{tabular}{lllll}
\hline \multirow{2}{*}{ Category } & \multicolumn{4}{c}{ Region } \\
\cline { 2 - 5 } & Kenten & Jambi & Lampung & P Pinang \\
\hline Weak & BN-N & BN-N & BN-N & BN-N \\
Moderate & BN-AN & BN-N & BN-N & BN-N \\
Strong & BN-N & BN & BN-N & BN-N \\
\hline
\end{tabular}

Based on the El Nino intensity category in the southern Sumatra region, generally, the average composite when El Nino with various categories (weak, medium, and strong) the percentage of events above $50 \%$ (bold type) in the nature of rain $\mathrm{BN}$ to $\mathrm{BN}$ dominant occurs at Palembang, Jambi, Lampung, and Pinang base stations. The influence of El Nino is strong in this region in all categories of El Nino intensity as described in TABLE 6. The percentage of BN rain properties is weak (50-58\%), moderate (36-56\%), and strong (32-60\%). 
TABLE 6. Composite averages of the years of EL Nino occurrence in various categories (Weak, Medium and Strong).

\begin{tabular}{|c|c|c|c|c|c|}
\hline \multirow{2}{*}{ No } & \multirow{2}{*}{ Station } & \multirow{2}{*}{$\begin{array}{l}\text { Rainfall } \\
\text { Characteristic }\end{array}$} & \multicolumn{3}{|c|}{ El Nino } \\
\hline & & & Weak & Moderate & Strong \\
\hline \multirow{3}{*}{1} & \multirow{3}{*}{ Palembang } & $\mathrm{BN}$ & $58 \%$ & $56 \%$ & $60 \%$ \\
\hline & & $\mathrm{N}$ & $29 \%$ & $26 \%$ & $27 \%$ \\
\hline & & AN & $13 \%$ & $18 \%$ & $12 \%$ \\
\hline \multirow{3}{*}{2} & \multirow{3}{*}{ Jambi } & $\mathrm{BN}$ & $56 \%$ & $33 \%$ & $11 \%$ \\
\hline & & $\mathrm{N}$ & $31 \%$ & $37 \%$ & $32 \%$ \\
\hline & & $\mathrm{AN}$ & $52 \%$ & $33 \%$ & $15 \%$ \\
\hline \multirow{3}{*}{3} & \multirow{3}{*}{ Lampung } & $\mathrm{BN}$ & $56 \%$ & $31 \%$ & $52 \%$ \\
\hline & & $\mathrm{N}$ & $33 \%$ & $43 \%$ & $33 \%$ \\
\hline & & $\mathrm{AN}$ & $11 \%$ & $26 \%$ & $15 \%$ \\
\hline \multirow{3}{*}{4} & \multirow{3}{*}{ Pangkalpinang } & $\mathrm{BN}$ & $50 \%$ & $36 \%$ & $50 \%$ \\
\hline & & $\mathrm{N}$ & $36 \%$ & $31 \%$ & $35 \%$ \\
\hline & & AN & $13 \%$ & $34 \%$ & $15 \%$ \\
\hline
\end{tabular}

\section{Water vapor pattern and EI Nino index}

The results of the analysis characteristic of the rainfall show a different characteristic of the El Nino effects in the two regions. Rainfall in the northern region varies between $\mathrm{BN}$ and $\mathrm{AN}$, meanwhile, in the south, it is generally BN-N. Rainfall forming factors are identified from the moisture content in the atmosphere of Sumatra. Water vapor analysis was done to see the content characteristics in both regions. In a period of June-July-August, during the dry season period, the correlation between precipitable water and Nino. 3.4, the correlation is generally higher with a correlation of 0.5 compared with north $(\mathrm{r}<0.3)$ as shown in FIGURE 4.a. This pattern shows that the water vapor content in Sumatra, in the southern part of the country, decreases when the surface temperature in the central Pacific region rises. Meanwhile in the northern shows a weaker association with sea surface temperatures in the Pacific region. This condition causes variability in rainfall in the northern and southern parts of Sumatra in the ENSO period.

Meanwhile, on the right side, in a period of December-January-February (DJF), during the rainy season, rising sea level temperatures in the Western Pacific region did not reduce rainfall in the Sumatra region but even increased rainfall especially in the West Coast region of Sumatera (FIGURE 4.a). From the two characteristics, there are differences in water vapor content in the two regions. 


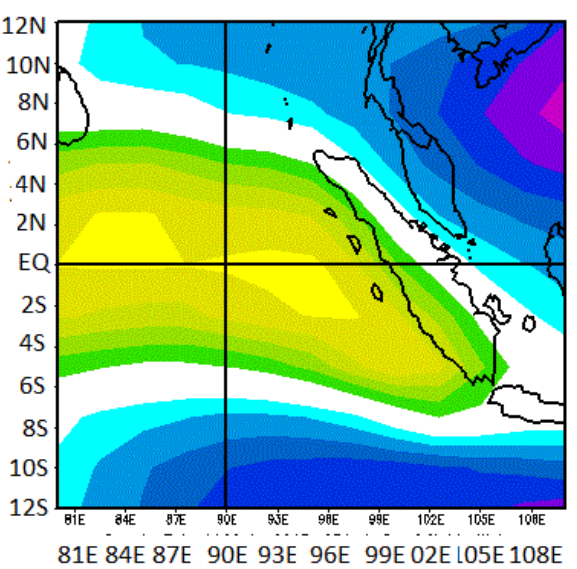

DJF

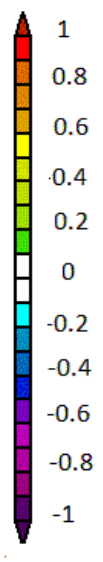

(a)

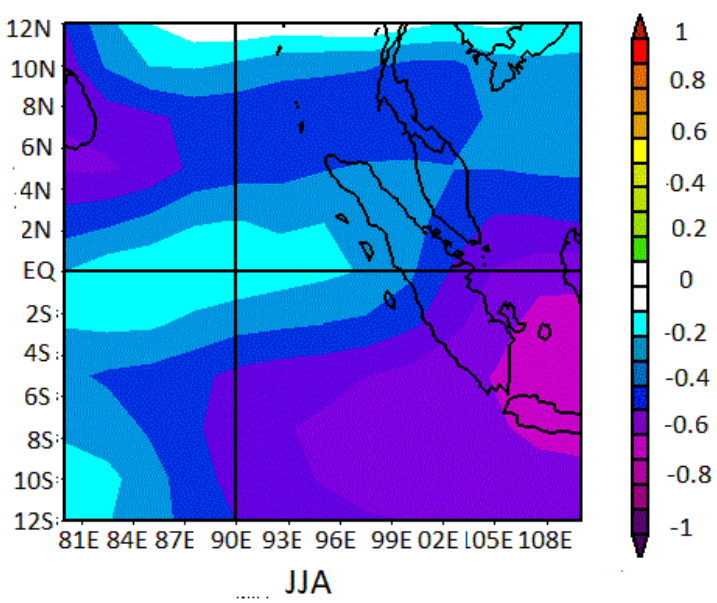

(b)

FIGURE 4. Correlation of Nino Index 3.4 and Precipitable Water (PW) in Sumatra and surrounding areas. DJF (December-January-February) b. JJA (June-July-August).

From the water vapor content $\left(\mathrm{kg} / \mathrm{m}^{2}\right)$, the monthly condition of correlation between PW and Nino index of 3.4 from February to May, shows the strengthening of sea surface temperature in Nino 3.4, water vapor content increases with a correlation value of 0.3. In June, the changes began until October, where there were shifting correlations in the north and south. An increase in PW occurs in a period of November-December-January as shown in FIGURE 5.
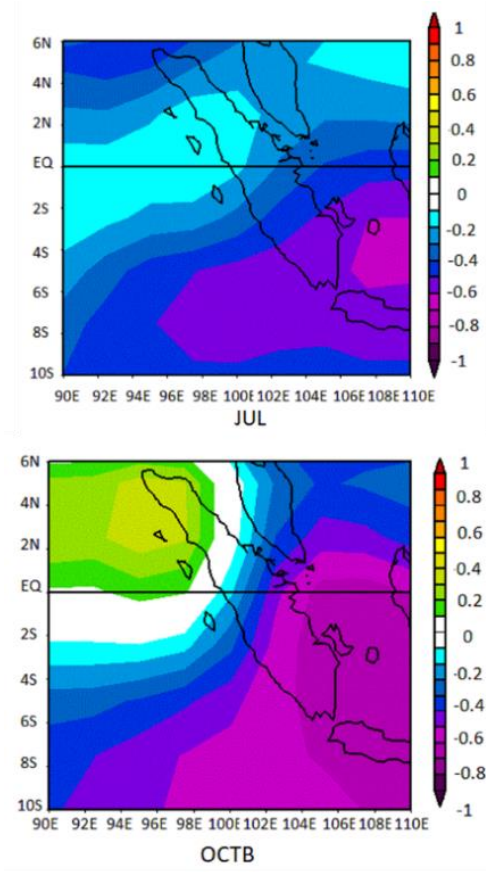
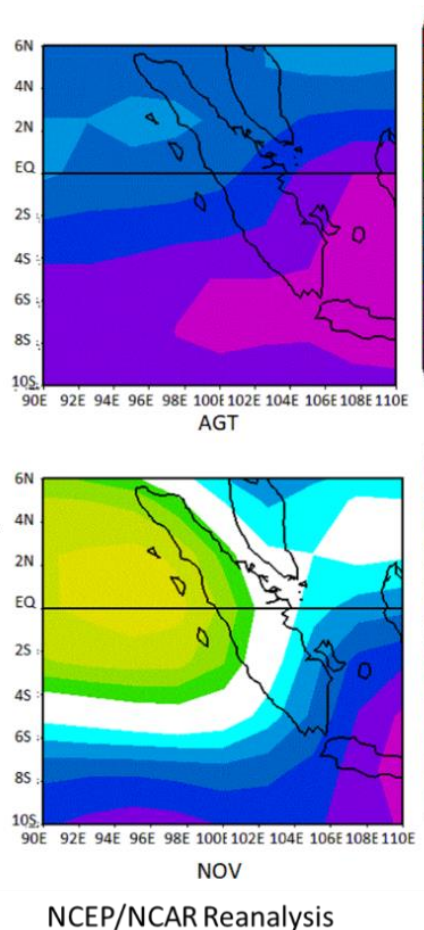
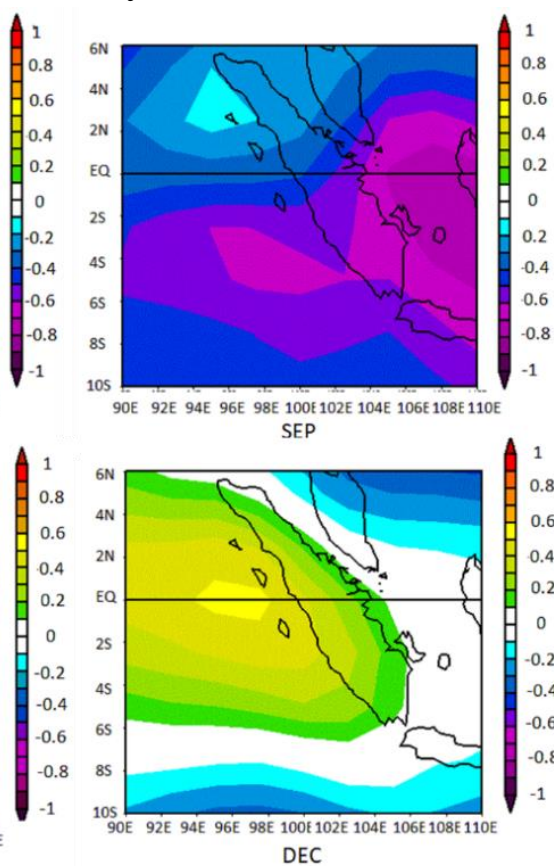

NOAA/ESRL Physical Sciences Division

FIGURE 5. Correlation of Nino Index 3.4 and Monthly Precipitable Water in Sumatra and Surrounding Areas 1986-2015. 
FIGURE 5 shows that there are different PW characteristics pattern of the two regions in Sumatra. In February Nino 3.4 did not correlate strongly with the Sumatra region again north and positively correlated with PW in the southern Sumatra region. The moisture content in March is not much different from March. In April, the water vapor content began to come to the west coast of northern Sumatra and evenly until deep with a positive correlation in May. From this pattern, there is a clear difference between northern and central Sumatra in FebruaryApril. The northern Sumatra region is not closely related to the Nino Index area 3.4. In May both regions were affected by the Nino Index. 3.4. Starting in July-October there were clear differences between North and South Sumatra. In November-December-January, there were no significant differences related to the Nino Index 3.4. This analysis shows the differences occur in February-April and July October associated with anomalous patterns (rainy season).

The results of previous studies indicate that there is a relationship between ENSO and rainfall in the Western Indonesia region, but it has not been detailed in the semi-annual and annual basis [20]. In general, the influence of semi-annual and annual was obtained in detail in this research. The influence of these two regions is different because the level of association with ENSO is different in the two regions.

\section{CONCLUSION}

Based on the character analysis of the rain nature and PW, the effect of El Nino (in the annual rain cycle) is stronger than in areas with a semi-annual rain cycle. The annual rain cycle area in the El Nino intensity category is weak, moderate, and strong, by showing the dominant rainfall properties of $\mathrm{BN}$ $\mathrm{N}$. Whereas, in the semi-annual rain cycle the El Nino intensity categories are weak (the characteristic of rainfall among $\mathrm{N}-\mathrm{AN}$ ), moderate (characteristic of $\mathrm{BN}-\mathrm{AN}$ ), and strong $(\mathrm{N}-\mathrm{BN})$. The average percentage of composites in El Nino in the two regions also shows the influence in Sumatra with an annual pattern is stronger than semi-annual. North Sumatra region has a weak intensity with average $\mathrm{BN}$ rain characteristic between $37-50 \%$, moderate (42-53 (and strong (42-48\%)), whereas in the annual cycle area the average rainfall characteristic of BN rain category is weak ( 50-58\%), moderate (36$56 \%$ ), and strong (32-60\%). The characteristics of this rain are different in two regions because there are differences in the ability of the atmosphere to store water vapor (precipitable water). The correlation pattern in the area with the rain cycle (June-July-August) between precipitable water (Nino Index 3.4) and water vapor content showed a strong correlation (r) (-0.4 to -0.6). This shows that if the sea surface temperature at pacific is rising, the water vapor content in areas with annual rainfall cycles has fallen, unlike in the semi-annual rainfall cycle region which shows a weaker correlation $(0.2-0.3)$.

\section{ACKNOWLEDGMENT}

The author would like to say thank you to the head of STMKG who has given research funding and the Climatology Station of the Meteorology Climatology and Geophysics Agency who has provided data for research. 


\section{REFERENCES}

[1] I. Athoillah, R. M. Sibarani and D. E. Doloksaribu, "Analisis Spasial El Nino Kuat Tahun 2015 Dan La Nina Lemah Tahun 2016 (Pengaruhnya Terhadap Kelembapan, Angin dan Curah Hujan di Indonesia)," Jurnal Sains \& Teknologi Modifikasi Cuaca, 2017, vol. 18, no. 1 .

[2] C. P. Chang et al., "On the relationship between western maritime continent monsoon rainfall and ENSO during northern winter," Journal of Climate, 2004, vol. 17, no. 3.

[3] E. Aldrian and R. Dwi Susanto, "Identification of three dominant rainfall regions within Indonesia and their relationship to sea surface temperature," International Journal of Climatology: A Journal of the Royal Meteorological Society, 2003, vol. 23, no. 12.

[4] C. P. Chang et al., "Annual cycle of Southeast Asia-Maritime Continent rainfall and the asymmetric monsoon transition," Journal of climate, 2005, vol. 18, no. 2.

[5] A. N. U. Khoir and A. Safril, "The influence of strong El Niño to seasonal variability in Sumatera," AIP Conference Proceedings, 2018, vol. 1987, no. 1.

[6] H. Irwandi et al., "The Influence of ENSO to the Rainfall Variability in North Sumatra Province,” IOP Conference Series: Materials Science and Engineering , 2018, vol. 335, no. 1.

[7] H. H. Hendon, "Indonesian rainfall variability: Impacts of ENSO and local air-sea interaction,” Journal of Climate, 2003, vol. 16, no. 11.

[8] B. HE et al., "Interannual variability in the onset of the South China Sea summer monsoon from 1997 to 2014," Atmospheric and Oceanic Science Letters, 2017, vol. 10, no. 1.

[9] E. Mulyana, "Analisis Angin Zonal di Indonesia Selama Periode ENSO,” Jurnal Sains \& Teknologi Modifikasi Cuaca, 2002, vol. 3, no. 2.

[10] V. R. Durai, S. K. R. Bhowmik and H. R. Hatwar, "Distribution of precipitable water contents over Indian monsoon region,” MAUSAM, 2007, vol. 58, no. 2.

[11] R. Wang et al., "Evaluation of atmospheric precipitable water characteristics and trends in mainland China from 1995 to 2012," Journal of Climate, 2017, vol. 30, no. 21.

[12] K. Kanemaru and H. Masunaga, "A satellite study of the relationship between sea surface temperature and column water vapor over tropical and subtropical oceans," Journal of climate, 2013, vol. 26, no. 12.

[13] E. Lu et al., "Precipitation and precipitable water: Their temporal-spatial behaviors and use in determining monsoon onset/retreat and monsoon regions," Journal of Geophysical Research: Atmospheres, 2009.

[14] N. Lu et al., "Trends and variability in atmospheric precipitable water over the Tibetan Plateau for 2000-2010," International Journal of Climatology, 2015, vol. 35, no. 7.

[15] H. Li and B. Chen, "The evolution of precipitable water associated with the Asian and Australian monsoons as revealed from MODIS/SSMI, ECMWF and NCEP reanalysis data sets," Geophysical research letters, 2005, vol. 32, no. 10.

[16] D. E. Poan et al., "West African monsoon intraseasonal variability: A precipitable water perspective," Journal of the atmospheric sciences, 2013, vol. 70, no. 4. 
[17] G. Chen, Y. N. Takayabu and C. Yokoyama, "Synoptic-scale dual structure of precipitable water along the eastern Pacific ITCZ," Journal of climate, 2014, vol. 27, no. 16.

[18] B. Xie, Q. Zhang Q and Y. Ying, "Trends in precipitable water and relative humidity in China: 1979-2005," Journal of applied meteorology and climatology, 2011, vol. 50, no. 10.

[19] Noersomadi, "Analisis Precipitable Water Vapor dari Data Gps Radio Occultation dan Radiosonde," Prosiding Seminar Penerbangan dan Antariksa 2010 Sub Seminar Sains Atmosfer dan Iklim Serpong, 2010.

[20] Badan Meteorologi Klimatologi dan Geofisika, "Prakiraan Musim Kemarau Indonesia 2019," 2019. 